УДК 159.9:168

DOI https://doi.org/10.26661/2310-4368/2021-1-2

\title{
ПСИХОЛОГІЧНИЙ СУПРОВІД АДАПТАЦІЙНОГО ПРОЦЕСУ ЗДОБУВАЧІВ ВИЩОЇ ОСВІТИ В КАРАНТИННИХ УМОВАХ
}

\author{
Бугерко Я. М. \\ кандидат психологічних наук, доцент, \\ дочент кафедри психологї та сочзільної роботи \\ Західноукраӥнський національний університет \\ вул. Львівська, 11, Тернопіль, Украӥна \\ orcid.org/0000-0002-9138-5350 \\ Ja.buherko@gmail.com
}

\author{
Ключові слова: сочіально- \\ психологічна адаптація, \\ адаптованість особистості, \\ психологічний супровід \\ освітнього прочесу, \\ психологічна самоізоляція, \\ пандемія COVID-19, \\ адаптащчійний ресурс \\ освітнього середовищу, \\ здобувачі $3 В О$.
}

У статі розглянуто адаптацію як процес і результат активно-дієвого ставлення людини до світу, проаналізовано особистісну адаптованість як відносно сталу тенденцію-результат життєактивності людини і водночас психоформу внутрішнього світу особистості, специфічно людську внутрішню систему відліку, яка самоорганізує інші психічні утворення і виявляється як універсальна здатність особи гармонізувати свої взаємини зі світом і самою собою. Показано, що адаптація студентів до навчання в закладі вищої освіти в умовах карантину є складним багатофакторним процесом, який містить п'ять взаємопов' язаних етапів: первинну реакцію, орієнтування, внутрішню переробку і осмислення, вибір адаптаційної стратегії, продуктивну взаємодію. Визначено змістовну характеристику, домінантні компоненти-індикатори та показники успішного проходження кожного етапу. Зазначено, що порушення процесу адаптації на окремих етапах стосуються тих компонентів, на які лягає найбільше навантаження, і які є показниками (індикаторами) самого етапу. Вирізнено такі основні типи порушень: 1) невдала реалізація (неадекватне виконання) основного завдання конкретного етапу; 2) пропуск етапу; 3 ) фіксація на певному етапі; 4) регресія (повернення) до попереднього етапу. Виявлення відхилень від оптимальної моделі адаптаційного процесу дає змогу визначити ключові проблеми й точково-конструктивні напрями їх подолання. Це особливо важливо в умовах карантину, коли використання традиційних методів дослідження процесу адаптації обмежене. Виокремлення складників адаптивного ресурсу (як особистості, так і освітнього закладу) на кожному етапі адаптаційного процесу дає змогу побудувати ефективну програму психосоціальної підтримки учасників освітнього процесу, спрямовану на розвиток їхніх адаптивних можливостей. На прикладі функціонування освітнього процесу ЗУНУ показано, що конструктивно вибудований психологічний супровід освітнього процесу дає можливість якісно підвищити показники особистісного адаптаційного потенціалу здобувачів вищої освіти та оптимізувати процес їх адаптації до навчання в карантинних умовах. 


\title{
PSYCHOLOGICAL SUPPORT OF THE HIGHER EDUCATION APPLICANTS' ADAPTATION PROCESS IN QUARANTINE CONDITIONS
}

\author{
Buherko Ya. M. \\ Candidate of Psychological Sciences, Associate Professor, \\ Associate Professor at the Department of Psychology and Social Work \\ West Ukrainian National University \\ Lvivska str., 11, Ternopil, Ukraine \\ orcid.org/0000-0002-9138-5350 \\ Ja.buherko@gmail.com
}

\begin{abstract}
Key words: socio-psychological adaptation, personality adaptability, psychological support of the educational process, psychological selfisolation, COVID-19 pandemic, an adaptive resource of the educational environment, higher education applicants.
\end{abstract}

\begin{abstract}
In the article, an adaptation is considered as the process and result of an active human attitude to the world, personal adaptability is analyzed as the relatively constant trend-result of human activity and at the same time the psychoform of the inner world of the individual that is the specifically human internal frame of reference which self-organizes other mental formations and manifests itself as the universal ability of a person to harmonize their relationships with the world and itself. It is shown that the adaptation of students to study in a higher education institution in quarantine is a complex multifactorial process that contains five interrelated stages: initial response, orientation, internal processing and understanding, the choice of adaptation strategy, productive interaction. Meaningful characteristics, dominant components-indicators, and indicators of successful completion of each stage are defined. It is noted that the violations of the adaptation process at certain stages relate to those components that bear the greatest load, and which are indicators (indicators) of the stage itself. The following main types of violations are distinguished: 1) unsuccessful implementation (inadequate performance) of the particular stage main task; 2) skipping the stage; 3) fixation at a certain stage; 4) regression (return) to the previous stage. Detection of deviations from the optimal model of the adaptation process allows identifying key problems and point-constructive directions of overcoming them. This is especially important in quarantine when the use of traditional methods of studying the process of adaptation is limited. Isolation of the components of the adaptive resource (both individual and educational institution) at each stage of the adaptation process allows you to build an effective program of psychosocial support for participants in the educational process, aimed at developing their adaptive capabilities. The example of the educational process at WUNU shows that the constructive psychological support of the educational process allows qualitatively increasing the personal adaptive potential of higher education applicants and optimizing the process of their adaptation to learning in quarantine conditions.
\end{abstract}

Постановка проблеми. Складні умови сьогодення висувають перед людиною вимогу відповідати соціальним нормативам i, водночас, зберігати внутрішню стабільність та рівновагу. Серйозним випробуванням для усіх верств населення стала пандемія COVID-19. Під час карантину істотно змінився ритм і спосіб життя в зовсім нових умовах, суттєво змінилось інформаційно-комунікативне поле, відбувся перерозподіл часу звичних робочих, навчальних i побутових практик. Хронічне перебування в ситуації високої невизначеності стало викликом для багатьох людей, зокрема для студентської молоді. А тому надзвичайно важливим $€$ питання пристосування до нових соціальних умов та налагодження продуктивної освітньої взаємодії.

Аналіз останніх досліджень і публікацій. Питанню адаптації, вивчення іii форм, видів, механізмів перебігу, приділяється значна увага. Так психологічні особливості адаптації аналізуються в працях Г.О. Балла, О.І. Гринчук, С.П. Іваненкова, В.А. Петровського, О.О. Шльонської, М.С. Яницкого та ін.; особистісну адаптованість як універсальну здатність особи гармонізувати свої взаємини із світом і самою собою досліджували О.В. Кузнєцова, І.С. Ревасевич, О.П. Сан- 
нікова, А.В. Фурман; особливості адаптації до професійної діяльності через поняття самореалізації особистісних можливостей, особистісного потенціалу розкриваються у працях Ж.П. Вірної, Є.В. Карпенка, П.С. Кузнєцова, А.О. Реана та ін.

Воднораз аналіз літератури засвідчує недостатню вивченість проблеми взаємодії особистості і соціального освітнього середовища, практично відсутні публікації, котрі б висвітлювали специфіку протікання адаптивного процесу в карантинних умовах і стосувалися б вивчення адаптивних властивостей особистості, ii ресурсів та адаптаційного потенціалу. Багатоплановий, комплексний, характер проблеми соціально-психологічної адаптації до умов карантину потребує грунтовного дослідження.

Мета статі - обгрунтування структурно-функціональної організації процесу соціально-психологічної адаптації здобувачів 3ВО в умовах карантину та розробка програми соціально-психологічного супроводу, спрямованої на розвиток адаптаційного потенціалу студентів, підвищення рівня їх адаптивності.

Виклад основного матеріалу дослідження. Широкий інтерес до проблеми адаптації людини засвідчує багатогранність та універсальність адаптивних явищ, тому цей феномен слід розглядати із міждисциплінарних позицій як багаторівневе явище складноорганізованої біологічної, фізіологічної, психологічної та соціальної природи. Однак для сучасних досліджень характерним $є$ термінологічна неузгодженість, а іноді і певна підміна понять словами-синонімами («звикання», «пристосування», «входження», «становлення», «прийняття» та ін.). Аналіз наукової літератури 3 даної проблематики дозволяє зробити висновок, що адаптацію можна розглядати як процес, стан, властивість або результат діяльності, який виникає при певних умовах, триває протягом певного періоду, поки не буде встановлено динамічної рівноваги між системами, які адаптуються $[2 ; 4 ; 6 ; 7 ; 9]$.

Низка дослідників, аналізуючи феномен адаптації, визначає різницю між адаптацією як процесом і адаптованістю як іiі результатом. На думку Ж. Піаже, Л. Хьєлл, добре адаптована людина це людина, у якої не порушені психічна рівновага, продуктивність і здатність насолоджуватися життям [за 5, с. 35]. Зазначимо і значні напрацювання вітчизняних психологів. Так, проф. А.В. Фурман уточнює, що адаптація як процес характеризує рівень суб'єкта, а як результат - це рівень особистості. На думку науковця, «коли мова йде про перебіг адаптаційних процесів, структуру і динаміку адаптаційної активності, то слід говорити про «адаптивність, не- чи дезадаптивність» людини як суб'єкта своєї життєдіяльності, а коли має місце оформленість психічних процесів у вигляді станів i комплексів (страх, депресія, невротизм тощо), то правильним $\epsilon$ уживання термінів «адаптованість, не- чи дезадаптованість» особистості» $[9$, c. $15-16]$.

О.П. Саннікова виділяє таку властивість особистості як адаптивність, котра забезпечуе врівноваженість взаємозв'язків особистості з мікро- та макросоціальним середовищем завдяки здатності як до внутрішньо-психологічних так і зовнішньо-поведінкових перетворень. Дослідниця виділяє формально-динамічний (базисний), змістовно-особистісний та соціально-імперативний рівні адаптивності [7].

Аналіз поняття «адаптивність» показав, що існують неоднозначні його тлумачення. 3 одного боку, під адаптивністю розуміється певна характеристика поведінки людини, що відбиває узгодженість іiі цілей і результатів активності (функціональний аспект), 3 іншого - адаптивність розглядається як окрема системна властивість індивідуальності, що постає як здатність до адаптації (особистісний аспект). А тому доцільно говорити про особистісну адаптованість як про специфічно людську внутрішню систему відліку, яка «не просто самоорганізує інші психічні утворення - ставлення, оцінки і самооцінки, суб'єктне прийняття, психічний образ, психологічну ситуацію, Я-концепцію, а й виявляється як універсальна здатність особи гармонізувати свої взаємини із світом і самою собою, тобто постійно відновлювати і збагачувати відповідність: а) зовнішньо між ментальним досвідом людини і оточенням, б) внутрішньо - між цілями і результатами, ставленнями і психічними образами, переживаннями $\mathrm{i}$ Я-концепцією» [6, с. 284].

I.C. Ревасевич, розглядаючи структуру особистісної адаптованості як відносно сталу тенденцію-результат життєактивності людини і водночас психоформу внутрішнього світу особистості, вводить поняття актуальної лінії адаптації. Це своєрідна межа між пристосуванням людини у зовнішньому світі і її внутрішньою адаптивністю. Якщо iii діапазон широкий, то у людини проявляються високі адаптивні можливості. Відомо, що навіть людина із дуже високим рівнем пристосованості час від часу все ж таки потрапляє в ситуації неадаптованості. Однак вона реагуватиме на них за умов добре розвиненої актуальної лінії адаптації позитивним ставленням, повноцінним їх суб'єктивним прийняттям, відчуттям повної внутрішньої безпеки [там само].

Пандемія COVID-19, зважаючи на іiі масштабність, стала значним випробуванням для українського суспільства і всього людства. Вона вплинула на всі аспекти життя кожної людини, змінила звичний ритм і спосіб життя. Заборона 
спілкування, ізоляція людей у своїх помешканнях, табу на всі соціальні контакти, окрім родинних, on-line навчання та дистанційна трудова діяльність - все це стало не тільки вимогою на рівні законодавчо-правових актів, які були ухвалені парламентами багатьох країн, зокрема i Україною, але й реальністю, до якої потрібно було швидко адаптуватися усім, без винятку, людям [1]. Звичний активний темп життя людей загальмувався, стиль життя - кардинально змінився, а відтак певних змін зазнали людські цінності та інтенції. Однією 3 найбільш уразливих верств населення у цій форс-мажорній ситуації, стало студентство, оскільки його ритм життя, порівняно 3 іншими віковими групами, був одним 3 найбільш темпоральних і швидко змінюваних у часі та просторі $[12 ; 14]$.

Аналіз сучасних медико-психологічних досліджень показує, що введення режиму самоізоляції і карантину без належного психологічного супроводу може викликати віддалені ефекти порушень психічного та психологічного здоров'я людини, а також непередбачувані соціальні наслідки для всього суспільства. В умовах ізоляції на психіку людини вливає комплекс факторів, зокрема, сенсорна деривація, обмеження простору, виникає синдром психічної астенізації, за якого підвищується подразливість та емоційна лабільність. Окрім того, в цих умовах можуть знижуватися когнітивні здібності, оскільки людському мозку для нормальної роботи потрібна значна різноманітність сигналів 3 навколишнього середовища. У результаті знижуються і пізнавальні функції пам'ять, увага, мислення, і функції контролю над взаємодіями $[10 ; 11]$.

У період карантину можуть виникати різні психічні стани людини, які є порівняно стійкими i пов'язані 3 напруженістю через зміни умов життєдіяльності, обмеження активності і свободи переміщення. Важливу роль у виникненні адаптивних перебудов особистості, пов'язаних 3 наявністю важких життєвих ситуацій, відіграє рівень активності особистості, ступінь іiі мобілізації. Як показали дослідження Л.В. Куликова, найбільш адекватним $є$ виділення оптимального рівня активності особистості. Емпіричні дані показують, що як за недостатньої, так і за надмірної мобілізації особистості 3 великою ймовірністю виникають психічні стани, які порушують адаптивну рівновагу. Так, за недостатньої мобілізації у важкій життєвій ситуації досить ймовірне виникнення апатії і зниження витрачання енергії. 3 іншого боку, в ситуації надлишкової мобілізації виникає стан високої напруги на фоні надмірного витрачання енергії [5, с. 57].

Адаптація студентів до навчання у вищому навчальному закладі є складним та багатогранним процесом, а його успішність залежить від низки зовнішніх та внутрішніх чинників. Сучасні дослідження показують, що якщо студент успішно адаптується до нових соціальних умов, студентського колективу, його норм та цінностей, то в нього є більше можливостей накопичити досвід для подальшої професійної діяльності. Водночас, виникнення певних труднощів у процесі адаптації може суттєво впливати як на навчальну діяльність, так і на соматичний та психоемоційний стан здобувача вищої освіти [3; 8].

Весна 2020 року для студентів Західноукраінського національного університету (тоді ще THЕУ), як і для всього українського студентства, виявилася особливою - початок семестру співпав у часі з розпалом пандемї COVID-19. У рекордно короткий час закладу довелося перелаштуватися на навчання он-лайн. Процес, який за нормальних умов зайняв би кілька років, вдалося реалізувати впродовж лічених тижнів. Звичайно, далеко не все відбулося ідеально, але вдалося зробити значний крок у напрямку диджиталізації системи вищої освіти. Нові реалії стали викликом як для студентів, так і для викладачів та керівництва навчального закладу.

Конструювати нову соціальну реальність через посередництво інформаційних платформ та відео-конференцій виявилося не зовсім легкою справою, оскільки достатніх навичок у цьому процесі не вистачало ні у викладачів вищих навчальних закладів, ні у студентів. Посилені вимоги до дистанційної освіти у ЗВО, зростаюча кількість нормативних актів у цьому напрямку, безумовно, неоднозначно впливало на соціально-психологічні настрої їх учасників, змінювало погляди на характер освітнього процесу. Тому важливим завданням було створення широкої системи психоедукативних програм та психосоціальної підтримки всіх учасників освітнього процесу. Першочерговою потребою став аналіз соціально-психологічних умов та детермінант успішної адаптації до нових умов навчання. Якщо раніше формат онлайн-роботи не мав масового розповсюдження і лише іноді використовувався як допоміжний, то світова пандемія внесла корективи у розуміння та використання такого формату. Він став єдиною доступною учасникам освітнього процесу формою взаємодії [1; 3; 13]. Варто зазначити, що нові умови роботи потребували адаптації не лише 3 боку студентів, а й викладачів. Істотно зросло навантаження на викладачів, багато 3 яких до ситуації з епідемією не мали досвіду роботи у віртуальному середовищі. За статистичними даними 2019 року чверть викладачів вузів із вченим ступенем раніше не використовували сервіси віддаленого відеозв'язку для участі в вебінарах i відео конференціях [1]. Водночас відзначимо, що 
вимушена онлайн освіта дала значний простір для творчості та академічної свободи викладача при формуванні та наповненні освітнього контенту на обраній платформі.

Для вивчення адаптаційного процесу в умовах карантину було проаналізовано наявний теоретичний матеріал i вироблено методологічні підходи по створенню програми вивчення адаптованості здобувачів вищої освіти. Ми виходили 3 положення, що загальна ефективність адаптаційного процесу суттєво залежить від складних інтеграційних тенденцій особистості. Адаптація як складне явище має певну структуру, котра містить низку відносно незалежних процесів. Водночас кожен структурний компонент процесу адаптації є системою, яка містить: а) об'єктивне явище і його умови (зовнішні умови); б) відносини адаптанта з відповідним явищем (ставлення, стосунки, зв'язки); в) індивідуальні особливості самої людини, що відповідають чи не відповідають вимогам (внутрішні умови або власні ресурси людини). Створену модель адаптаційного процесу представлено на рис. 1.

Процес адаптації розгортається в часі, має кілька етапів і торкається практично всіх компонентів особистості. Зміни, що відбуваються в особистості можна відстежити на трьох рівнях: емоційному, когнітивному і поведінковому. Емоиійний компонент описує загальний емоційний стан студента і його ставлення до ситуації, що змінилася. Когнітивний компонент визначає ступінь інформованості особистості про ситуацію та ступінь орієнтування в проблемній ситуації. На поведінковому рівні розглядається активність здобувача освіти, спрямована на перетворення ситуації. При цьому активність може виражатися у вигляді зовнішньої поведінки, а може виступати у формі внутрішньої активності, спрямованої на перетворення власної особистості.

У процесі соціально-психологічної адаптаціï, при послідовному переході 3 одного етапу на інший, різні компоненти (емоційний, когнітивний і поведінковий) набувають неоднакової значимості. Навантаження ніби переноситься 3 одного рівня на інший, залежно від тих завдань, які доводиться вирішувати особистості в процесі побудови нової системи взаємодії з середовищем. Водночас межі між послідовними стадіями процесу можуть бути досить розмиті, проте, компонент, котрий несе найбільше навантаження на певному етапі, як правило, найбільш яскраво виражений. Відповідно, за розподілом внутрішніх ресурсів особистості між емоційним, когнітивним i поведінковим компонентами можна визначити етап процесу адаптації в конкретний момент. Було виділено п'ять взаємопов'язаних етапів в єдиному процесі соціально-психологічної адаптації: первинна реакція на зміни, орієнтування, внутрішня переробка і осмислення, вибір адаптаційної стратегіï, продуктивна взаємодія та побудована програма їх вивчення (табл.).

Виокремлення зазначених етапів адаптаційного процесу виявилось особливо ефективним для аналізу адаптації саме в умовах дистанційного навчання, коли відсутня (або вкрай обмежена) можливість використовувати класичні методи дослідження (різнопланові діагностичні методики, корекційно-тренінгові заняття тощо). Оскільки реальна соціально-психологічна адаптації протікає не завжди успішно, тому виявлення відхилень від зазначеної оптимальної моделі адаптаційного процесу дозволяє виявити ключові проблеми і точково-конструктивні напрями їх подолання. Зазначимо, що порушення процесу адаптації на окремих етапах стосуються саме тих компонентів, на які лягає найбільше навантаження, і які є показниками (індикаторами) самого етапу. Вирізнено такі основні типи порушень: 1) невдала реалізація (неадекватне виконання) основного завдання конкретного етапу; 2) пропуск етапу; 3 ) фіксація на певному етапі, 4) регресія (повернення) до попереднього етапу. Причини

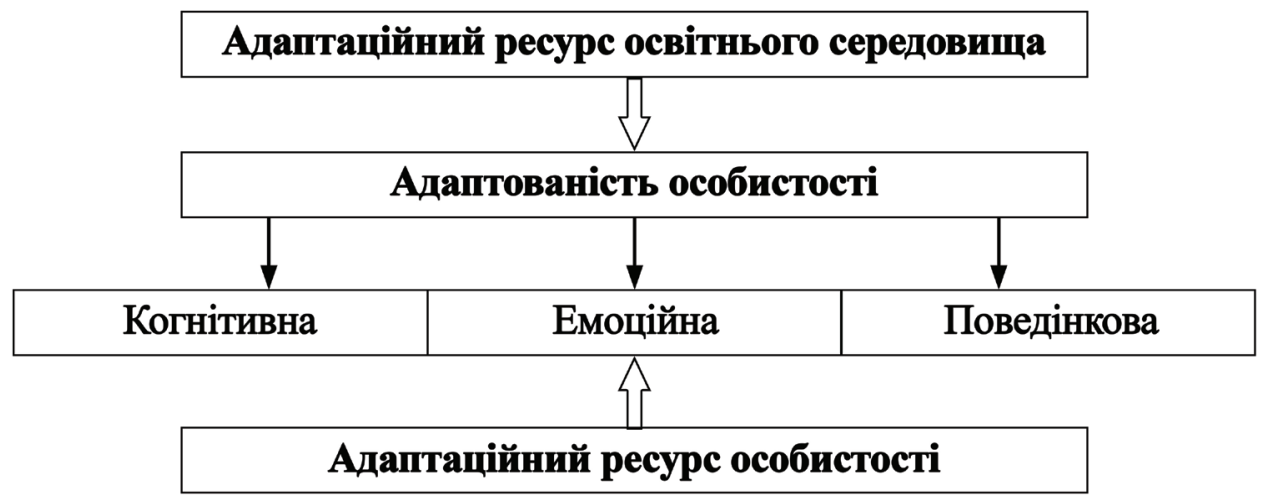

Рис. 1. Модель соціально-психологічної адаптації здобувачів ЗВО 
Таблиця 1

Аналіз структурних складників процесу соціально-психологічної адаптації здобувачів ЗВО

\begin{tabular}{|c|c|c|c|c|c|}
\hline \multirow{2}{*}{$\begin{array}{c}\text { Стадії адап- } \\
\text { таційного } \\
\text { процесу }\end{array}$} & \multirow{2}{*}{$\begin{array}{c}\text { Ключова } \\
\text { змістовна } \\
\text { характерис- } \\
\text { тика етапу }\end{array}$} & \multirow[b]{2}{*}{$\begin{array}{l}\text { Домінуючий } \\
\text { компонент }\end{array}$} & \multirow{2}{*}{$\begin{array}{c}\text { Показник } \\
\text { успішного про- } \\
\text { ходження етапу }\end{array}$} & \multicolumn{2}{|c|}{ Використання адаптаційного ресурсу } \\
\hline & & & & $\begin{array}{c}\text { особистості здобува- } \\
\text { ча вищої освіти }\end{array}$ & $\begin{array}{c}\text { освітнього середови- } \\
\text { ща університету }\end{array}$ \\
\hline $\begin{array}{l}\text { 1. Первинна } \\
\text { реакція на } \\
\text { зміни }\end{array}$ & $\begin{array}{l}\text { Зростання } \\
\text { емоційної } \\
\text { напруги }\end{array}$ & Емоційний & $\begin{array}{l}\text { Прийняття факту } \\
\text { зміни ситуації }\end{array}$ & $\begin{array}{l}\text { Індивідуально-пси- } \\
\text { хічні властивості: } \\
\text { толерантність до } \\
\text { стресу, нервово-пси- } \\
\text { хічна стійкість }\end{array}$ & $\begin{array}{l}\text { - формування інфор- } \\
\text { маційного середови- } \\
\text { ща в університеті, } \\
\text { - розширення ка- } \\
\text { налів комунікації } \\
\text { (Instagram, ін.) }\end{array}$ \\
\hline $\begin{array}{l}\text { 2. Орієнту- } \\
\text { вання }\end{array}$ & $\begin{array}{l}\text { Чутливість до } \\
\text { релевантної } \\
\text { інформації }\end{array}$ & Когнітивний & $\begin{array}{l}\text { Адекватна орієн- } \\
\text { тація в ситуації }\end{array}$ & $\begin{array}{l}\text { Самооцінка особи- } \\
\text { стості, адекватність } \\
\text { сприйняття умов } \\
\text { діяльності та своїх } \\
\text { можливостей }\end{array}$ & $\begin{array}{l}\text { - моніторинг адапта- } \\
\text { ційних проблем; } \\
\text { - розроблення психо- } \\
\text { логічних і методич- } \\
\text { них рекомендацій; } \\
\text { - наповненість } \\
\text { онлайн курсів систе- } \\
\text { ми Моodle }\end{array}$ \\
\hline $\begin{array}{l}\text { 3. Внутрішня } \\
\text { переробка і } \\
\text { осмислення }\end{array}$ & $\begin{array}{l}\text { Високий } \\
\text { рівень } \\
\text { внутрішньої } \\
\text { активності }\end{array}$ & $\begin{array}{l}\text { Когнітивний, } \\
\text { мотиваційний }\end{array}$ & $\begin{array}{l}\text { Формування вну- } \\
\text { трішньої позиції } \\
\text { особистості, но- } \\
\text { вих поведінкових } \\
\text { стереотипів }\end{array}$ & $\begin{array}{l}\text { Рефлексивність, при- } \\
\text { йняття ризику, } \\
\text { соціально-нормативні } \\
\text { ціннісні установки }\end{array}$ & $\begin{array}{l}\text { - онлайн-формат ка- } \\
\text { федральних і загаль- } \\
\text { ноуніверситетських } \\
\text { заходів } \\
\text { - інститут куратор- } \\
\text { ства та студентського } \\
\text { наставництва }\end{array}$ \\
\hline $\begin{array}{l}\text { 4. Вибір } \\
\text { адаптаційної } \\
\text { стратегії }\end{array}$ & $\begin{array}{l}\text { Активні пере- } \\
\text { творювальні } \\
\text { дії }\end{array}$ & Поведінковий & $\begin{array}{l}\text { Діï, спрямовані } \\
\text { на зміну пове- } \\
\text { дінки }\end{array}$ & $\begin{array}{l}\text { Поведінкова гнуч- } \\
\text { кість, відчуття } \\
\text { соціальної підтрим- } \\
\text { ки, почуття власної } \\
\text { значущості }\end{array}$ & $\begin{array}{l}\text { - електронна система } \\
\text { управління і контро- } \\
\text { лю освітнім процесом } \\
\text { (електронні журнали, } \\
\text { відомості, ін.) }\end{array}$ \\
\hline $\begin{array}{l}\text { 5. Продуктив- } \\
\text { на взаємодія }\end{array}$ & $\begin{array}{l}\text { Установка на } \\
\text { оптимальну } \\
\text { взаємодію і } \\
\text { самореаліза- } \\
\text { цію }\end{array}$ & $\begin{array}{l}\text { Емоційний, } \\
\text { поведінковий }\end{array}$ & $\begin{array}{l}\text { Стан адаптовано- } \\
\text { сті особистості }\end{array}$ & $\begin{array}{l}\text { Відкритість досвіду, } \\
\text { прийняття відпові- } \\
\text { дальності, прагнен- } \\
\text { ня особистісного } \\
\text { зростання }\end{array}$ & $\begin{array}{l}\text { - чітка взаємодія всіх } \\
\text { ланок освітнього } \\
\text { процесу, } \\
\text { - постійний моні- } \\
\text { торинг і зворотний } \\
\text { зв'язок усіх учасників } \\
\text { освіти }\end{array}$ \\
\hline
\end{tabular}

порушень можуть бути різні і часто пов'язані 3 відсутністю або недостатнім функціонуванням певних адаптивних властивостей особистості. Виокремлення складників адаптивного ресурсу (особистості і освітнього закладу) дозволили в подальшому конструктивно вибудовувати лінію психологічного супроводу освітнього процесу в умовах карантину.

Опитування, проведене в онлайн-форматі в березні 2020 року серед студентів 1-4 курсів ЗУНУ спеціальності «Психологія» та «Соціальна робота» 3 метою вивчення стану організації дистанційного навчання показало ключові проблеми, 3 якими зіткнулися студенти. Більшість опитаних позитивно оцінили організацію навчання в дистанційному форматі, а також підготовку університету і викладачів до переходу в онлайн - обидва пункти в не влаштували лише $11 \%$ учасників. При виясненні конкретних проблем, 3 котрими зіткнулися студенти в нових умовах навчання, одержані відповіді були як прогнозованими, так і дещо несподіваними. Найчастіше студенти відповідали, що їм не вистачає живого спілкування 3 одногрупниками і викладачами, скаржилися на технічні складності і перебої з Інтернетом. Значна кількість опитаних відмітили, що в домашній обстановці вчитися складніше, нелегко зосередитися при самостійному вивченні матеріалу, не завжди вдається уточнювати деталі у викладачів і відповідати на їхні запитання без прямого контакту. Врешті, студенти відчували себе більш самотніми при дистанційному форматі.

На запитання про проблеми, які виникли під час переходу на онлайн навчання було названо такі: не вистачає спілкування з одногрупниками - $47 \%$, виникають технічні проблеми з Інтернетом - $38 \%$, не вистачає очних дискусій з викладачами - $42 \%$, складно навчатись в домашній обстановці - $35 \%$, 
важко зосередитись під час самостійного вивчення матеріалу - 37 \%, відчувають себе самотніми, ізольованими під час дистанційного формату - 34 \%, складно відповідати на запитання викладача i уточнювати незрозуміле в онлайн-форматі - 32 \%, не можливість обговорити з одногрупниками матеріал, який вивчається - $20 \%$, складно втримувати увагу при перегляді відео лекцій - 25 \%, складно знайти зручне місце для занять в дистанційному форматі - $20 \%$, складно розібратись з інтерфейсом онлайн-курсів і програм дистанційного навчання 10 \%, нема відповідних пристроїв, які можна було б використати для дистанційного навчання - 9\%.

Результати показали, що найважче вчитись тим, хто ще не встиг набути достатнього досвіду навчання в університеті офлайн - першокурсникам. Їм важче самоорганізовуватися, концентруватися на самостійному вивченні матеріалу, зокрема при перегляді відео-лекцій, вивченні онлайн-курсів. До того ж їм важче відповідати на запитання викладача чи задавати уточнюючі запитання на заняттях онлайн. Швидкий вимушений перехід на дистанційний формат навчання прогнозовано відобразився на досвіді студентів. Значна частина (65 \%) відзначили зниження ефективності навчання. Водночас, незважаючи на всі труднощі, сформувалась i значна кількість прихильників онлайна. Приблизно третині опитаних дистанційний формат подобається більше ніж очна форма навчання.

Аналіз результатів опитування дозволив ідентифікувати труднощі та переваги впровадженого дистанційного навчання, серед недоліків якого технічні питання та психологічні проблеми, зокрема відсутність живого спілкування, неможливість повторної здачі пропущених практичних занять, значне збільшення завдань, брак часу на виконання завдань, зобов'язання виконувати свої сімейні обов'язки щодо контролю/догляду за молодшими братами (сестрами), обмежений доступ до комп'ютера, оскільки батьки теж переведені на віддалену роботу тощо. Серед психологічних проблем можна виділити дидактичні проблеми, пов'язані 3 навчанням (обсяг завдань, відсутність діалогу 3 викладачем тощо), мотиваційні (невизначеність власної стратегії навчання, низька самомотивація), емочійно-комунікативні (нестача живого спілкування 3 друзями, одногрупниками, викладачами). Зазначені проблеми тісно пов'язані між собою і вказують на складнощі в соціально-психологічній адаптації до нових умов навчання. А відтак нагальною постала потреба психологічного супроводу освітнього процесу в умовах карантину, створення умов, котрі сприяють оптимізації процесу адаптації здобувачів вищої освіти та підвищення адаптаційного потенціалу їх особистості.

Основними характеристиками психологічного супроводу є безперервність, постійність та ціліс- ність; можливість здійснення за умови взаємодії всіх учасників освітнього процесу. Основним агентом реалізації соціально-психологічного супроводу є психологічна служба університету, котра здійснює зазначену програму адаптації здобувачів вищої освіти до навчання в карантинних умовах на кількох рівнях: через роботу зі студентами, з викладачами, із органами студентського самоврядування та адміністрацією університету.

Ключовим завданням під час навчання в карантинних умовах на першому етапі адаптаційного процесу $\epsilon$ формування інформаційного середовища в університеті, максимально повне і швидке його оновлення i поповнення. При цьому важливим $€$ : використання сайту університету для інформування стосовно організації дистанційного освітнього процесу; навчально-методичний супровід онлайн-навчання; створення е-середовища спілкування між учасниками освітнього процесу, в тому числі, ведення блогів консультацій, збереження результатів співпраці здобувачів вищої освіти; обмін досвідом професорсько-викладацького складу університету; організація моніторингу і контролю дистанційного навчання. Не менш важливим в умовах карантинного навчання $€$ розширення каналів комунікації (соціальні мережі, найбільш популярні серед студентської молоді, зокрема Instagram, Facebook та ін.).

Наступне завдання соціально-психологічного супроводу - постійний моніторинг поточних проблем i труднощів 3 якими стикаються студенти в процесі дистанційного навчання. Це дає змогу запобігати серйозним ускладненням, вчасно i швидко надавати допомогу вже на початкових стадіях зародження проблеми. Наприклад, аналіз результатів опитувань студентів спеціальності «Психологія» та «Соціальна робота» дозволив згрупувати основні типові проблеми студентів у 4 блоки і організувати різнопланову роботу для допомоги в їх подоланні. При цьому були залучені різні структури і ланки навчального закладу для вирішення чітко конкретизованих завдань відповідно до їх компетенції. Так, зокрема для допомоги у вирішенні емоційно-мотиваційних проблем, 3 якими зіткнулись здобувачі вищої освіти в умовах карантину, психологічною службою університету було розроблено низку рекомендацій для студентів, котрі стосувалися загальних принципів саморегуляції в стресовій ситуації; рекомендацій стосовно організації навчання і роботи в умовах карантину (для студентів та для викладачів); рекомендації з профілактики несприятливих психічних станів в період дії карантину в зв'язку 3 Covid-19; поради 3 тайм-менеджменту для студентів в період незвичайної ситуації.

Складною проблемою дистанційного навчання є мотивація, а особливо, самомотивація здобувачів 
вищої освіти. Значну частину часу студенти проводять у самостійному освоєнні матеріалу, а для цього необхідні такі якості як постійний самоконтроль, наполегливість, висока концентрація уваги. Щоб допомогти у вирішенні зазначеної проблеми, для студентів були розроблені рекомендації «Прийоми і правила самомотивації», водночас для викладачів підготовлені рекомендації як підтримувати мотивацію і залученість студентів при поточній дистантній освіті, визначено стратегії підтримки продуктивних форм мотивації в онлайн навчанні.

Одним із суттєвих недоліків дистанційної форми навчання є комунікативні обмеження, які перешкоджають розвитку групової комунікації та групової єдності. Опитування показало, що нестача живого спілкування $є$ одним 3 найважчих факторів емоційного самопочуття, котре безпосередньо впливає i на успішність навчання. Як зазначають самі студенти, «онлайн-зустрічі не замінюють спілкування 3 друзями в університеті, спільних святкувань чи буденних розмов». Тому дуже важливим завданням $€$ вибудовування правильної комунікаційної траєкторії. Щоб мінімізувати негативні ризики даної проблеми, традиційні форми роботи теж змінили свій формат. У нашому університеті такі офлайн-заходи як міжфакультетські конкурси «Нова генерація», «Студентська Ліра» (для студентів нового набору), святкування Дня кафедри психології та соціальної роботи, які виконують важливу функцію згуртування студентського колективу, розвитку духовно-ціннісних та професійних орієнтацій були переведені в онлайн формат і активна участь в їх підготовці і проведенні студентів-першокурсників дозволила відчути атмосферу дієвого студентського життя і більш повно ознайомитися з особливостями майбутньої професії.

Зазначені та низка аналогічних заходів, зокрема, постійно діючий на факультеті «Суботній неформат «Без краваток»»» відіграють особливо важливу роль на третій стадіï адаптаційного процесу, активно задіюючи мотиваційні та когнітивні компоненти, формуючи соціально-нормативні ціннісні установки здобувача вищої освіти та водночас сприяючи процесу професіоналізації майбутнього фахівця. Водночас відмітимо, що успішне проходження зазначеного етапу адаптації сприяє формуванню внутрішньої позиції особистості та вибору ефективної стратегії адаптивної поведінки.

Адаптаційні стратегії реалізуються засобами підвищення активності студентів у пристосуванні до умов навчально-професійної діяльності, дієвого ставлення до навколишньої дійсності, усвідомлення мотивів власної поведінки та вироблення ефективних стратегій їх реалізації; самостійного врахування точності, швидкості, повноти, емоційності, вміння відбирати, аналізувати, використовувати інформацію у процесі освітньої діяльності, осмислення інформації, формування наукових понять та розвиток особистісної і професійної рефлексії.

Для успішного протікання зазначеного етапу адаптаційного процесу важливу роль відіграє інститут кураторства та студентського наставництва (старшокурсників над новачками). Перевагою останнього є можливість здійснення різноманітними шляхами і засобами відповідно до конкретної ситуації, зорієнтованість на особистість та іiї внутрішню систему цінностей.

Найважливішим етапом, який засвідчує ефективність протікання адаптаційного процесу, $є$ етап продуктивної освітньої взаємодї, котрий характеризується установкою на особистісне зростання і самореалізацію. Для його успішної реалізації оптимально задіюються як особистісні ресурси здобувачів, так і можливості освітнього потенціалу закладу вищої освіти.

Результативність впровадженої системи психологічного супроводу підтверджують результати багаторівневого особистісного опитувальника «Адаптивність» А.Г. Маклакова, С.В. Чермяніна, проведеного серед здобувачів вищої освіти, котрі звернулись із запитами у психологічну службу університету (рис. 2).

Зростання рівня поведінкової регуляції та комунікативного потенціалу особистості студентів (виражене зменшенням абсолютних значень даних показників) показують істотне підвищення здатності студентів ефективно регулювати свою взаємодію із освітнім середовищем, вибудовувати взаємовідносини з іншими людьми, досягати контакту і взаєморозуміння. Це забезпечує ефективність процесу соціально-психологічної адаптації завдяки зростанню особистісного адаптаційного потенціалу студентів. Водночас, така складова адаптаційного потенціалу особистості як моральна нормативність, котра відображає сприйняття морально-етичних норм поведінки i ставлення до вимог безпосереднього соціального оточення, залишилась практично без змін. Стосовно цього висловимо кілька зауважень. Щонайперше, варто зазначити плюси, які дала система вимушеного дистанційного навчання, зокрема виникнення нових форм роботи і проектів, розвиток нових компетенцій, зміцнення особистих зв'язків всередині об'єднання за рахунок збільшення кількості індивідуальної роботи і рефлексії, розширення географії учасників (завдяки використання в процесі навчання вебінарів, воркшопів). Усе це сприяє зростанню зацікавленості студента в набутті нових знань, усвідомленню їх необхідності для подальшого професійного зростання і побудови кар'єри, а отже активно включає такі важливі фактори особистісної адаптованості як ціннісно-смисловий та рефлексивний. 


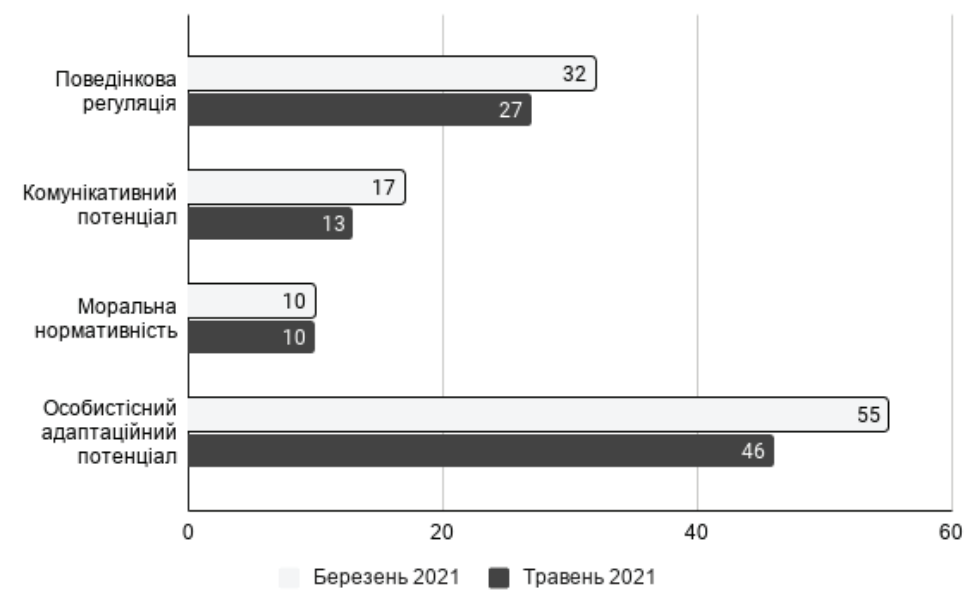

\section{Рис. 2. Динаміка змін компонентів адаптаційного потенціалу особистості (методика «Адаптивність» А.Г. Маклакова, С.В. Чермяніна, вибірка 28 осіб)}

Однак варто зазначити, що університетська освіта - це не лише лекції та семінари, а й спільна проектна робота студентів і викладачів, спілкування, обмін ідеями, з яких кожен в кінцевому підсумку отримує нові можливості і треки розвитку. А тому тотальний вимушений перехід на онлайн-навчання закладів вищої освіти, 3 одного боку, надав позитивний поштовх пошуку нових форм і методів освітнього процесу, однак, 3 іншого - створив загрозу зниження якості надання освітніх послуг, тому існує потреба знайти розумний компроміс між повним переходом навчання у віртуальний простір і традиційною очною освітою.

Висновки. Адаптація студентів до навчання у ЗВО в умовах карантину є складним багатофакторним процесом, який містить п'ять взаємопов'язаних етапів: первинну реакцію, орієнтування, внутрішню переробку і осмислення, вибір адаптаційної стратегії, продуктивну взаємодію. Аналіз особливостей їх протікання дозволяє побудувати ефективну програму психосоціальної підтримки учасників освітнього процесу, спрямовану на розвиток адаптивних можливостей та підвищення резистентності психіки особистості до впливу несприятливих чинників.

Розроблена програма соціально-психологічного супроводу освітнього процесу в умовах карантину оптимізує перебіг процесів навчання, виховання та розвитку особистості, при цьому залишає за самим студентом право на вибір подальших дій і не знімає з нього відповідальності за свої рішення та дії. Подальшого уточнення потребує взаємозв'язок рівнів адаптованості особистості студентів та вплив адаптаційного потенціалу освітнього середовища на здатність вибудувати успішний життевий та професійний шлях майбутнього фахівця.

\section{ЛІТЕРАТУРА}

1. Досвід переживання пандемії Covid-19: дистанційні психологічні дослідження, дистанційна психологічна підтримка: матеріали онлайн-семінарів / [за наук. ред. М.М. Слюсаревського, Л.А. Найдьонової, О.Л. Вознесенської]. Київ : ІСПП НАПН України, 2020. 121 с.

2. Ващенко І.В., Іваненко Б.Б. Психологічні ресурси особистості в подоланні складних життєвих ситуацій. Проблеми сучасної психології. Вип. 40. Кам’янець-Подільський : Аксіома, 2018. С. 33-49.

3. Зюзь В., Балухтіна В. Тайм-менеджмент як фактор адаптації студентів до дистанційного навчання у ЗВО в період надзвичайної ситуації. Актуальні питання гуманітарних наук. Вип. 28, т. 2, 2020. C. 93-98.

4. Новікова Ж.М. Психологічна адаптація та преадаптація студентів-першокурсників в умовах нестабільного світу. Молодий вчений. 2018. № 2 (54). С. 80-83.

5. Реан А.А., Кудашев А.Р., Баранов А.А. Психология адаптации личности. Анализ. Теория. Практика. Санкт-Петербург, 2006. 479 с.

6. Ревасевич I. Особистісна адаптованість як складна психоформа життєактивності людини. Вітакультурна методологія: антологія: колективна монографія. Тернопіль : ТНЕУ, 2019. C. 283-285.

7. Санникова О.П., Кузнецова О.В. Системный анализ адаптивности личности : монография. Одесса: Издательство ВМВ, 2017. 392 с. 
8. Соколовская И.Э. Социально-психологические факторы удовлетворенности студентов в условиях цифровизации обучения в период пандемии COVID-19 и самоизоляции. Цифровая соииология. 2020. Т.3, № 2. С. 46-54.

9. Фурман А.В. Психодіагностика особистісної адаптованості. Тернопіль : Економічна думка, 2000. 197 c.

10. Brammer S., Clark T. COVID-19 and Management Education: Reflections on Challenges, Opportunities, and Potential Futures. British Journal of Management. 2020. Vol. 31. P. 453-456.

11. Fernández R.S., Crivelli, L., Guimet N.M., Allegri R.F., Pedreira M.E. Psychological distress associated with COVID-19 quarantine: Latent profile analysis, outcome prediction and mediation analysis. Journal of affective disorders. 2020. 277. P. 75-84.

12. Moreno-Fernandez J., Ochoa J.J., Lopez-Aliaga I., Alferez M.J.M., Gomez-Guzman M., Lopez-Ortega S., Diaz-Castro J. Lockdown, Emotional Intelligence, Academic Engagement and Burnout in Pharmacy Students during the Quarantine. Pharmacy. 2020. 8(4). P. 184-194.

13. Owen P. Hall. Editorial: COVID-19 and the Future of Management Education. 2020. Vol. 23. P. 1-6.

14. Sun S., Goldberg S.B., Lin D., Qiao S., Operario D. Psychiatric symptoms, risk, and protective factors among university students in quarantine during the COVID-19 pandemic in China. Globalization and Health. 2021. 17 (1). P. 1-14.

\section{REFERENCES}

1. Sliusarevskyi, M. (Eds.). (2020). Dosvid perezhyvannia pandemii Sovid-19: dystantsiini psykholohichni doslidzhennia, dystantsiina psykholohichna pidtrymka [Experience of the Covid-19 pandemic: remote psychological research, remote psychological support] : materialy onlain-seminariv. Kyiv, 121 [in Ukrainian].

2. Vashchenko I.V., Ivanenko B.B. (2018). Psykholohichni resursy osobystosti v podolanni skladnykh zhyttievykh sytuatsii [Psychological resources of the personality in overcoming difficult life situations] Problemy suchasnoi psykholohii. Vyp. 40. Kamianets-Podilskyi : Aksioma, 33-49 [in Ukrainian].

3. Ziuz, V., Balukhtina V. (2020). Taim-menedzhment yak faktor adaptatsii studentiv do dystantsiinoho navchannia u ZVO v period nadzvychainoi sytuatsii [Time management as a factor of adaptation of students to distance learning in higher education institutions during an emergency]. Aktualni pytannia humanitarnykh nauk. Vol. 2, 28, 93-98 [in Ukrainian].

4. Novikova Zh.M. (2018). Psykholohichna adaptatsiia ta preadaptatsiia studentiv-pershokursnykiv v umovakh nestabilnoho svitu [Psychological adaptation and preadaptation of first-year students in an unstable world]. Molodyi vchenyi. 2 (54), 80-83 [in Ukrainian].

5. Rean, A.A., Kudashev, A.R., Baranov, A.A. (2006). Psykholohyia adaptatsyy lychnosty. Analyz. Teoryia. Praktyka [Psychology of personality adaptation. Analysis. Theory. Practice]. Sankt-Peterburh, 479 [In Russian].

6. Revasevych, I. (2019). Osobystisna adaptovanist yak skladna psykhoforma zhyttieaktyvnosti liudyny [Personal adaptability as a complex psychoform of human life] Vitakulturna metodolohiia: antolohiia. Ternopil, 283-285 [in Ukrainian].

7. Sannykova, O.P., Kuznetsova, O.V. (2017). Systemnyj analiz adaptivnosti lichnosti [System analysis of personality adaptability]. Odessa, 392 [In Russian].

8. Sokolovskaia Y.E. (2020). Sotsyalno-psykholohycheskye faktoru udovletvorennosty studentov v uslovyiakh tsyfrovyzatsyy obuchenyia v peryod pandemyy COVID-19 y samoyzoliatsyy [Socio-psychological factors of students 'satisfaction in the context of digitalization of education during the COVID-19 pandemic and self-isolation]. Tsyfrovaia sotsyolohyia. T.3, 2,46-54 [In Russian].

9. Furman A.V. (2000). Psykhodiahnostyka osobystisnoi adaptovanosti. . [Psychodiagnostics of personal adaptability] Ternopil, 197 [in Ukrainian].

10. Brammer S., Clark T. (2020). COVID-19 and Management Education: Reflections on Challenges, Opportunities, and Potential Futures. British Journal of Management. Vol. 31, 453-456.

11. Fernández, R.S., Crivelli, L., Guimet, N.M., Allegri, R.F., \& Pedreira, M.E. (2020). Psychological distress associated with COVID-19 quarantine: Latent profile analysis, outcome prediction and mediation analysis. Journal of affective disorders, 277, 75-84

12. Moreno-Fernandez, J., Ochoa, J.J., Lopez-Aliaga, I., Alferez, M.J.M., Gomez-Guzman, M., Lopez-Ortega, S., \& Diaz-Castro, J. (2020). Lockdown, Emotional Intelligence, Academic Engagement and Burnout in Pharmacy Students during the Quarantine. Pharmacy, 8(4), 184-194.

13. Owen P. Hall. (2020). Editorial: COVID-19 and the Future of Management Education. Vol. 23 , 1-6.

14. Sun, S., Goldberg, S.B., Lin, D., Qiao, S., \& Operario, D. (2021). Psychiatric symptoms, risk, and protective factors among university students in quarantine during the COVID-19 pandemic in China. Globalization and Health, 17(1), 1-14. 